\title{
Model of Integrated Disaster Awareness Community To Community Learning Center (CLC) in Bantul and Sleman Distric
}

\author{
Iis Prasetyo ${ }^{a}$, Entoh Tohani ${ }^{b}$, RB. Suharta ${ }^{c}$ \\ Nondormal Education Department Yogyakarta State University \\ Yogyakarta \\ Corresponding e-mail: aiis.prasetyo@uny.ac.id, Entoh_tohani@uny.ac.id, suhartapls@gmail.com
}

\begin{abstract}
These study aimed to describe: 1) the disaster awareness community in Bantul and Sleman; 2) disaster awareness community activities in Bantul and Sleman; 3) Model of Disaster-awareness community integrated to CLC. This study uses qualitative methods to describe the model of disaster-awareness communities that developed in Sleman and Bantul districts before and after the 2006 earthquake and Merapi eruption in 2010. Data obtained through observation and interviews with disaster-awareness community managers and volunteers. The results showed: 1) disaster awareness community in Bantul and Sleman has been able to carry out their roles and functions in disaster alleviation. This community is largely initiated by the community in cooperation with the government and disaster relief agencies and Basarnas; 2) disaster awareness community have been doing a lot of disaster-related activities such as handling the disaster, emergency response training, counseling disaster, mapping the disaster area, talk shows, making a documentary video, the provision of learning resources for the utilization of the local potential, and agricultural training. Currently the disaster awareness community has not been involved CLC in implementing trending activities; 3) model of integrated disaster awareness community to CLC emphasis on three main activities, namely management, activity or programs and infrastructure. cooperationg between CLC and disaster awareness community manner is a form of mutual cooperation.
\end{abstract}

Keywords: community learning center, disaster, disaster awareness community

\section{INTRODUCTION}

Indonesia is an archipelago country located in the Pacific Ocean region which is famous for the Ring of Fire. Not only in Indonesia, the region's ring of fire spread to the Americas with a coverage area of a length of $40,000 \mathrm{~km}$. Besides known as the ring of fire, this region is also commonly known as the Pacific seismic belt where large earthquakes often occur in this region. Ring of fire region as shown in the figure 1.

The picture shows the disaster-prone areas caused by shifting tectonic plates and volcanic activity stretching in the Pacific Ocean. Besides, Indonesia is a country that is included in Alpide Belt region. Alpide belt extends from Java to Sumatra, the Himalayas, the Mediterranean to the Atlantic. The data showed $17 \%$ of large earthquakes located in this Alpide belt region. One example of the massive earthquake that occurred in the Alpide Belt region there is an Aceh earthquake on December 26, 2004 with a magnitude of 9.3 magnitude which is the largest earthquake in the span of 40 years

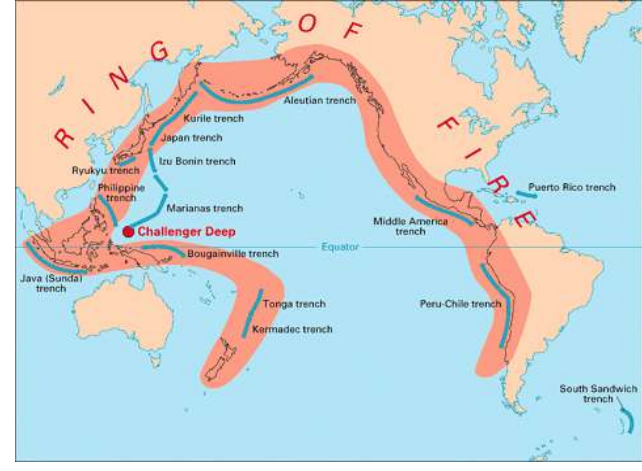

Figure 1. Pacific Seismic Belt

Source:

(http://id.wikipedia.org/wiki/Berkas:Pacific_Ring_of_Fire. png)

Java is one of the islands included in the Pacific Ring of Fire and Alpide Belt. Characterized by the presence of active volcanoes are almost evenly cover the region, ranging from Sunda Strait to East Java. One of the volcanoes are still active today is Merapi in Yogyakarta Province. This mountain has a regular cycle of eruptions that occurred between 4-5 years. Eruption of Mount Merapi, which is quite big happened last in 2010 
numbered of victims as much as 277 people died (www.slemankab.go.id), whereas The eruption in November 2013 is the initial symptoms to the cycle that is expected to occur in 2014.

The potential disaster in Yogyakarta Province besides the eruption of Mount Merapi is an earthquake. Province of Yogyakarta it self located on the southern island of Java has the potential for earthquakes is quite high compared to the northern region of the island of Java. An earthquake with a large scale occurred in 2006, epicenter in Bantul with magnitude 6.3 which killed over 5,700 people and more than 100,000 people homeless (news.nationalgeographic.com). The earthquake that occurred in 2006 was preceded by the eruption of Merapi, which occurs for several weeks in May 2006.

Today's, Disaster management is focus to give public conciousness about the importance of preventing and managing the disaster. One alternative can used to overcome the problem of low public awareness is forming a disasterconciousness group that has enough knowledge to overcome various disaster problems. Disaster conciuous group (community) is a community group that has commitment to environment and society, especially in the effort to face the disaster both natural disaster or other kind of disaster until the society which have resilience in facing disaster were formed.

The International Federation of Red Cross and Red Crescent Societies (IFRC) has defined the following disaster-awareness communities: Community disaster awareness (DA) initiatives which inform and train local populations about how to prepare for natural disasters and emergencies can reduce a population's vulnerability to specific hazards. These initiatives need not require large financial outlays nor do they require the work of a great number of people. What is required for planning purposes is a DA strategy that is opportunistic in its timing and which is integrated with other local and community development strategies (IFRC, 2000:5).

Disaster-awareness communities can be an individual activities such as going around in rural areas to conduct disaster awareness meetings, or sending leaflets or posters about disaster preparedness in the neighborhood. More comprehensive activity is to carry out a planned and coordinated series of activities, and a more effective approach at the community level is an integrated strategy between disaster awareness and larger communities such as health and others.

Activities that disaster-awareness communities can undertake include those relating to themes such as: 1) potential disasters, emergencies and hazards in a region, and their impacts; 2) the actions or behavior of local people who can avoid and prepare for disasters and hazard situations at low cost; 3) steps undertaken by government and head of disaster management unit in thinking to prevent, prepare and respond to disaster; and 4) public disaster warning information systems, evacuation routes, temporary shelters, and how and when this information can be communicated.

The activities that can undertake by disaster-awareness communities including: 1) potential disasters, emergencies and hazards in a region, and their impacts; 2) the actions or behavior of local people who can avoid and prepare for disasters and hazard situations at low cost; 3) steps undertaken by government and head of disaster management unit in thinking to prevent, prepare and respond to disaster; and 4) public disaster warning information systems, evacuation routes, temporary shelters, and how and when this information can be communicated.

Disaster awareness community as a society formed institution established independently has many weaknesses, one of them are weakness in resource. In addressing these weaknesses, the various activities undertaken by the disaster awareness community can be basically done through cooperation with the existing non-formal education institutions in the community, one of them is the Community Learning Center (CLC). Community learning center (CLC) is defined by Unesco (2007: 1) as: "a local place of learning outside the formal educatioan system. Located in both villages and other areas, it is usully set up and managed by local people in order to provide various learning opportunities for community development and improvement of the quality of life." Others argue that "CLC is a formal partnership of one or more schools / centers, public or private agencies and community groups, working together for the benefit of students, families, and communities" (Smith, 2005: 6).

The existence of CLC in the society, either initiated by government, private institution (NGO) or also its own community (Unesco, 
2007: 7) is expected to be the center of learning for every citizen. This means that it is possible for CLC to cooperate with disasterawareness communities in implementing various activities related to disaster management.

\section{RESEARCH METHODS}

This study used qualitative methods. Qualitative methods are used to extract information in depth based on the information given by the research subject naturally. The research was conducted in March - September 2014. The research was conducted in two districts of Bantul and Sleman, Daerah Istimewa Yogyakarta. subjects in this study were determined based on the purpose of the study itself. Based on the research objectives, the subject of research is the managers and volunteers of disaster-awareness communities in Bantul and Sleman. The determination of samples based on objectives is prioritized compared with the determination of probability sampling, with the aim of "selecting information-rich cases for in-depth investigation" (Patton, 1990: 169). Techniques used in data collection are interviews and observation and documentation activities. The data collected in this study is qualitative data in the form of words or sentences obtained during the study. Qualitative data analysis is done through data reduction procedure, data display and conclusion. As for the validity of triangulation technique data sources and methods will be used in this study.

\section{RESEARCH RESULT AND DISCUSSION}

\subsection{Description of Disaster- Awareness Community}

\subsubsection{LAPBA}

LAPBA is a volunteer organization whose membership is based on the local community of Purwobinangun Village Pakem Sleman. The aims of organization is to carry out humanitarian activities to reduce the risk of casualties both property and life caused by disaster of eruption of Merapi or other natural disasters in the village of Purwobinangun Pakem Sleman. this organization started from the awareness of members of the village security in disaster management that routinely occurred in the Merapi region. This organization has an important role as a liaison between the government and citizens in the development of the village. the other main role of this institution is as the executor of anticipation activity of potential security disturbance in Purwobinangun Pakem Sleman area.

Members' recruitment is determined by a team consisting of Commander, Counselor, two elders and members of Bhabinkamtibmas Purwobinangun Village. Filtering aims to get members who have volunteerism, loyalty to the organization. Members conduct monthly regular meetings every 19th (20th night) at Purwobinangun village hall.

\subsubsection{PASAG MERAPI}

Volunteer Pasag Merapi (Paguyuban Sabuk Gunung Merapi), is one of the disaster awareness community in District Cangkringan. Pasag Merapi is Paguyuban Merapi community established since 2001 has the same vision and mission to realize awareness, awareness and independence in maintaining the sustainability of the Merapi region.

Establishment of this community is a manifestation of the concern of the people in the area of Merapi to participate in preserve its life in facing the threat of primary, secondary and tertiary hazards from the eruption of Merapi. It is believed eruption cycle of Mount Merapi occurs every 4 years, but the threat from Erupi Mount Merapi can happen anytime. Pasag Merapi community together with the existing community in the area of Merapi attempt to build social order in the area of Merapi.

The scope of the working area of this community covers areas in two provinces, with 4 districts, 12 sub-districts and 62 villages. Membership Pasag Merapi consists of several elements of society who are in the Merapi region that has similarities in terms of vision and mission. Members of Pasag Merapi consist of individual community elements in the area of Disaster Prone Areas (KRB) 1, KRB 2 and and KRB 3 who care about disaster risk reduction in the area of Merapi. The members from outside of the Merapi region are required to have the same vision and mission with community. Until now the number of pasag merapi member reaches 3-4 thousand people covering Sleman, Boyolali, Magelang, and Klaten.

The community of Pasag Merapi cooperates with several disaster related partners, such as BNPB, BPBD, BPPTK, SAR, 
government and other institutions that are equal and transparent.

\subsubsection{Bumi Langit Institute}

Bumi Langit Institute is a community that seeks to build human life into harmony with nature. The presence of this institution is motivated by the experience of the founders who feel called to provide the best for human prosperity and the preservation of nature. Armed with experience, learned science, and support of its own funding facilities, the founder of the agency built a community of awareness disguises occupying three hectares of land in Wukirsarai District, Imogiri, Bantul.

The disaster-awareness community called Bumi Langit Institute has a goal to build a society that lives in harmony with nature. Their disaster meaning as something that arises because humans live in nature does not maintain sustainability and kebersinambuangan with nature. Nature is not interpreted as something evil, but everything that can give us benefit to humans when human actions do harmonious and not hostile to nature. This community supports or aspires to a permanent / sustainable and permanent human life with a sustainable nature.

\subsubsection{Forum Pengurangan Resiko Bencana (FPRB)}

Forum Pengurangan Resiko Bencana is the Village Disaster Management Agency, which acts as a facilitator and initiator of disaster management activities at the village level, established at the village level and has a role in disaster management, either individually or collectively with others. The juridical foundation of this Village PRB Forum is the Village Head's Decision. Members of this forum are village stakeholders, both government and non-government.

These forums in carrying out their activities are supported by both funding resources and facilities both from the village and from outside the village. This resource is derived from: a) Self-Help Villagers; b) APBDes / ADD; c) Satker / Musren / Stimulant; d) Special Projects; and e) Institutional Cooperation. At the level of village life, has a position as a village institution, which in carrying out its role will relate with other institutions at the village level.

\subsection{Description Awareness Activities \\ of Disaster Community}

Based on the results of the research, disaster-awareness community activities differ in both preventive activities, disaster management in the event of a disaster, and during the recovery or post-disaster period. The following table summarizes the activities of disaster-awareness communities.

Table 1. Disaster Awareness Activity

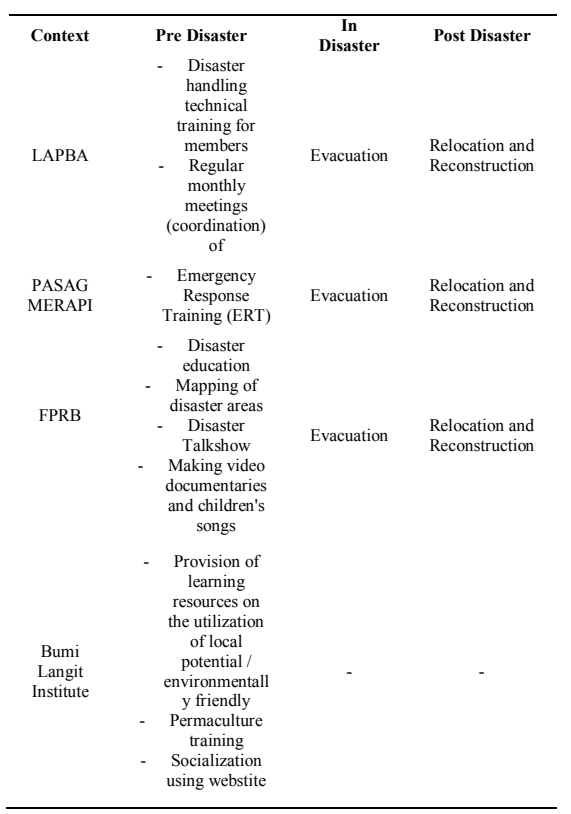

Seeing the implementation of the activities of each community, it appears that only the FRB has a diversity of educational activities in an effort to raise awareness of natural disasters directly addressed to groups or citizens. The results of the interviews show that the Forum seeks to provide insight through direct counseling and direct communication to local residents such as conveying materials on the importance of building a safe and secure home in neighborhood meeting forums and village karangtaruna. Although it was realized that talk show, film making, and song activities are still incidental. The relatively similar thing done is the training activities undertaken by Bumi Langit Institute where they regularly organize training activities for community members who generally come from outside the surrounding area; and training is also relatively expensive in terms of financing. 


\subsection{Model of Integrated Disaster Awareness Community To Community Learning Center (CLC)}

\subsubsection{Rational}

Increasing awareness of disasters is not merely the duties and responsibilities of the disaster awareness community, but it becomes the duty and responsibilities of all parties, including the community education institutions. CLC as an institution that serves to provide non formal education services for community members who have learning or education needs, certainly have an responsibility to develop public awareness and preparedness of disaster risk from the surrounding environment. CLC ideally has an education service that enables it to occur either through education, empowerment, and the provision of other information. Therefore, CLC needs to be involved in the handling of old disasters together with disaster-awareness communities.

The results showed that in disasterawareness communities do not have any activities that are done together or in partnership with CLC in the surrounding environment. CLC and disaster awareness communities each have separate or partial programs. The LAPBA community, Pasag Merapi, and Bumi Langit Institute have not had any cooperation to run the disaster awareness program with the nearest CLC. This is due to the ignorance of CLC functions and views that CLC is not an institution dealing with disaster issues. Even in LAPBA managers do not know which CLC is in their environment. Different things happen to FPRB where the personnel of this institution play a role in CLC. He runs the task as one of the tutors in CLC Tunas Harapan. As tutor, information about the importance of awareness of disaster, he conveyed in the process of learning equality education that exist in CLC. Another thing is the Forum also helped broadcast educational programs owned by local CLC.

The results showed that the disasterawareness community realized that the handling of natural disasters that occur in the community need to involve other parties one of them CLC. CLC is deemed to be able to provide educational activities on disaster such as being a source of learning for people who want knowledge about disaster, developing community learning design that leads to increase awareness of disaster, develop disaster learning media, environmental health learning, and so on. Disaster awareness community considers that disaster management activities will be easy to do if there is good cooperation with CLC.

\subsubsection{Community Based Disaster Information Management with CLC}

Based on the description, it can be concluded how all disaster-awareness communities have been able to manage knowledge or information about the disaster. However, the management of knowledge / information is limited to the management of knowledge and information that is responsive to the disaster that occurs and more tends to the technical disaster management. The results show that the community has not yet developed a knowledge management based on community needs that involves further the tupoksi being embedded in building a awareness and alert society in the disaster. Similarly, the resulting knowledge is more oriented to the community. For example, the management of knowledge related to the ability to utilize the natural potential that exists around the disaster area, resilience in the face of disaster.

Table 2. Disaster Information Management

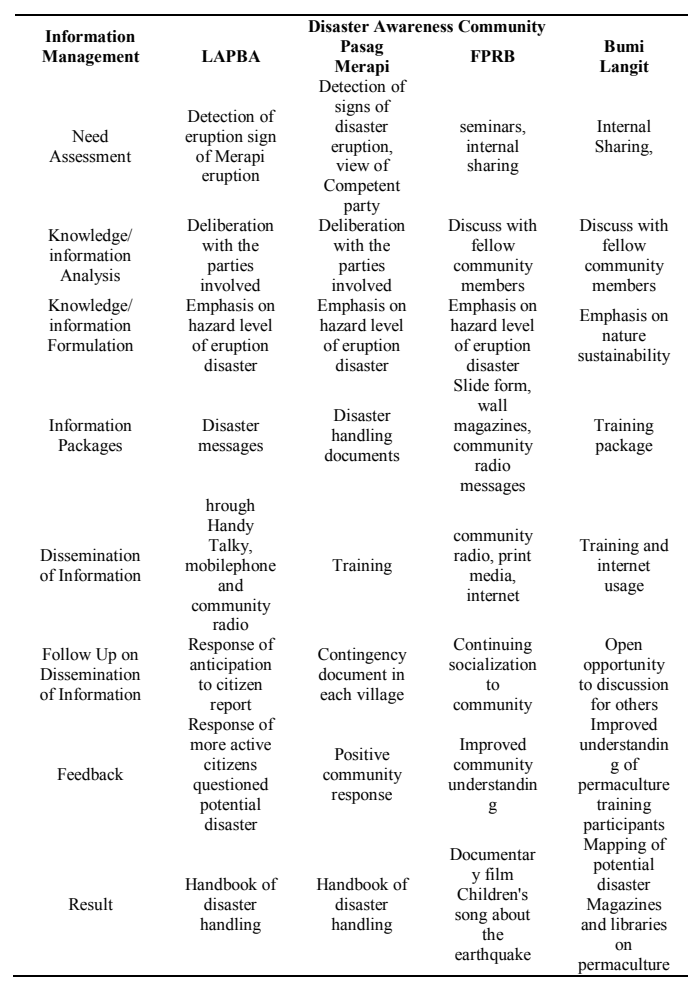




\subsubsection{Integration of Community Awareness Activities with CLC}

Disaster awareness community activities have differences both in preventive activities, disaster management in times of disaster, and during the recovery or post disaster. The following table summarizes the activities of disaster-awareness communities.

Table 3. Disaster Awareness Community Activity Involves Clc

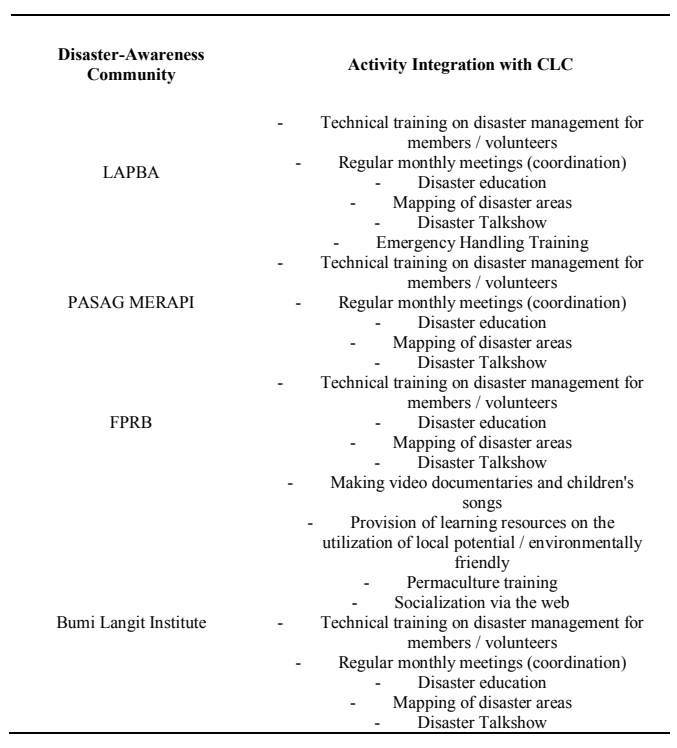

\section{CONCLUSIONS}

1. In Bantul and Sleman districts there are several communities participating in disaster management programs. Disasterawareness communities that has been identified including: LAPBA, PASAG Merapi, FPRB and the Bumi Langit Institute in Bantul District. The disaster awareness community largely initiated by the community in cooperation with the local government as well as the disaster management agency and basarnas.

2. Currently disaster-awareness communities have undertaken various activities such as disaster management, emergency response training, disaster counseling, disaster area mapping, talk shows, documentary video creation, provision of learning resources for local potential use, agricultural training, directed at strengthening community resilience against disaster.

3. Integration between disaster-awareness communities is focused on three aspects: management including managers, activities / programs and infrastructures. Managers in this case are required to have sensitivity to the needs of the community, especially in disaster management. On the one hand, CLC managers also need to coordinate with members / managers of disaster-awareness communities in order to meet the needs of the community. The second aspect is activity / program, where disaster-conscious community managers can cooperate with CLC in conducting various activities especially training, learning, socialization and training on disaster which the main target is society. The last aspect is the resources or infrastructure. In this case, the disaster awareness community cooperate with CLC to utilize every resource they have to prepare the community to face the disaster.

\section{REFERENCES}

[1] Patton, M. (1990). Qualitative evaluation and research methods. Beverly Hills, CA: Sage.

[2] Richard A. Lovett. (2006). Deadly Java Quake Highlights "Ring of Fire" Dangers. National Geographic News. Online pada: http://news.nationalgeographic.com/news /2006/05/060530-java-quake.html

[3] Smith, William J. (2005). The community learning centre, from values to result: Key issues and challenges for building and sustaining school-community collaboration. Quebec: LEARN.

[4] Unesco. (2008). CLC management handbook. Diakses dari www.unesco.org. diakses pada tanggal 12 Agustus 2008.

[5] Unesco. (2007). Strengthening community learning centre through linkages and networks: a synthesis of six country reports. Bangkok: Unesco Asia and Pasific Regional Bureau for Education.

[6] www. Slemankab. Go.id. (2010). Jumlah Korban Meninggal Bencana Erupsi Merapi. http://www.slemankab.go.id/1677/jumlah -korban-meninggal-bencana-erupsimerapi-per-tanggal-2-desember-2010mencapai-277-orang.slm 